\title{
Heat Storage Combined with Biomass CHP under the National Support Policy. A Case Study of Estonia
}

\author{
Anna VOLKOVA ${ }^{1 *}$, Eduard LATOSOV ${ }^{2}$, Andres SIIRDE ${ }^{3}$ \\ ${ }^{1-3}$ Department of Energy Technology, Tallinn University of Technology, Tallinn, 12616, Estonia
}

\begin{abstract}
In spite of the progressions in heat storage systems for combined heat and power' (CHP) plants performance, these innovations have not been implemented in CHP-based district heating (DH) systems in some of the countries where DH systems are still being developed. An examination of environmental and economic advantages that can be gained as a result of heat storage installation into the $\mathrm{DH}$ system are necessary to effectively popularise heat storage as a DH system-improvement technology. A real large-scale biomass CHP-based DH system is investigated in this case study. Scenarios for two kinds of support policies (feed-in premium for electricity generated by biomass CHP and energy-efficient biomass CHP) were analysed by changing the extent of the heat storage. The goal of this study was to assess the impact of the biomass CHP policy support instruments on the viability of integrating heat storage. Calculations demonstrate that fitting of heat storage combined with biomass CHP is less viable when all power generated by biomass CHP is subsidised.
\end{abstract}

Keywords - Accumulator tank; district heating; electricity market; feed-in premium; primary energy; thermal energy storage.

\section{INTRODUCTION}

The district heating (DH) sector has an essential impact on potential energy savings, allowing aggregated heat loads to gradually optimise energy supplies and transition to far more sustainable energy sources. Other benefits of DH include: reliable heat supply, reduction of heat generation costs, and possibility to use renewable energy sources [1], [2]. DH has been broadly utilised in a variety of places across Europe for years, both for domestic hot water (DHW) and space heating and supply. The latest overview of the existing DH systems, found in the Heat Roadmap Europe 2050 (a study covering the European Union member states) has shown that about 60 million of European residents, 287 regions and 141 cities are connected to DH [3]. In some European countries, where the climate is traditionally colder, such as Northern European countries (Latvia, Estonia, Lithuania) [4], [5] or Nordic countries (Denmark, Sweden and Finland) more than half of the residents have their heat provided by DH [6]. The DH system must transform and advance in order to be able to compete with other heat supply solutions, in accordance with the new conditions associated with renewable energy sources and buildings with low heat demand, as well as offer excellent customer service. In the last decade, the energy efficiency of DH systems has increased significantly, due, in part, to the introduction of the $4^{\text {th }}$ Generation DH concept in 2014, which presents ideas on the upgrades necessary for the future sustainable evolution of DH. This concept has been extensively reviewed by the international scientific community [7]-[9]. As indicated in the concept, one of the more significant conditions for the future sustainable DH system is

* Corresponding author.

E-mail address: anna.volkova@taltech.ee 
whether it is possible for the DH system to successfully integrate into smart energy systems. Smart energy systems by definition are the combination following smart grid infrastructures: electricity grids, thermal grids and gas grids [8], [10]. Short-term heat storage integration is an option for increasing heat load flexibility and improving CHP [11], waste incineration [12] and industrial excess heat [13] for heat supply. Long-term heat storage can improve a solar heating plant's operational efficiency [14]-[16]. Currently, the most common heat storage technology used in DH systems is an accumulator tank.

Usually, accumulator tanks are integrated within DH systems to make CHP operation more efficient. The main advantage of using the accumulator tank together with CHP is the reduction of heat and electricity production dependency on consumer heat load fluctuations. The appeal of using accumulator tanks with CHP plants has been explored in numerous studies.

Verda and Colella assessed the primary energy savings that could be achieved with the help of accumulator tank use together with CHP in DH, and proved that, with accumulator tank integration, more heat can be produced annually in CHP mode. An additional advantage is obtained by moving some of the heat production to night hours [17]. Nousson et al. analysed the wood biomass organic Rankyn cycle (ORC) CHP operation combined with a heat storage unit in an existing DH network, and concluded that the integration of a heat storage unit can lead to a marked increase in the overall system energy efficiency [18]. Wang et al. developed a method for modelling and optimising the CHP-based DH system, considering energy balances, power and heat storages. The results have shown that both the heat demand and cost of electricity have an impact on the optimal operation of the heat storage unit [19]. Streckiene and Misiviciute simulated thermal stratification on an accumulator tank combined with CHP, which was affected by the operation of heat generators on the spot market [20]. The studies that analysed the economic parameters of the heat storage integration mainly considered spot electricity prices. Another economic factor that may affect the feasibility of heat storage combined with CHP is associated with financial policy support tools aimed at reducing fossil fuel consumption in energy production, both for CHP electricity and renewable electricity support schemes. Anderssen and Ostergaard examined how the two CHP support schemes (feed-in tariffs and feed-in-premium tariffs) affect the size of CHP and heat storage capacity simultaneously. If an accumulator tank is integrated into a biomass CHP-based DH, national renewable energy support policy tools will affect its feasibility. Electricity produced from biomass is supported by most European countries, including Estonia. This paper presents the results of an examination on the effect of feed-in premium tariffs that have been introduced to support electricity production from biomass in Estonia, on heat storage feasibility.

The second section of the paper provides background information on the use of accumulator tanks in EU DH systems and discusses support schemes for electricity produced at CHP and from renewable energy sources in Estonia, and compares them with support schemes available in other European countries.

\section{BACKGROUND}

Heat storage is a system that can store heat to be used later under miscellaneous conditions, for example, temperature, location or storage tank type [21]. There are various heat storage types, including sensible heat storage (hot water accumulator tanks), latent heat storage, and thermochemical storage. The most commonly used technology for heat storage with CHP is the accumulator tank. Joint operation of CHP and an accumulator tank in a DH syste m brings several benefits, including stable heat production, with the accumulator tank acting as a buffer between production and fluctuating heat load. Additionally, the dependence between running 
the CHP plant and heat demand uncertainties can be reduced. Another advantage provided by heat storage is the extension of the period when heat can be produced in CHP mode.

Accumulator tanks have been widely used in European DH systems and in Northern countries (Sweden, Denmark, Iceland, and Finland) for several decades [22], [23]. For instance, over $75 \%$ of heat generated in Sweden is stored in accumulator tanks [24], and around $280 \mathrm{DH}$ plants are equipped with accumulator tanks in Denmark[18]. Accumulator tanks are also rather widespread in Austria and Germany [25].

Fig. 1 shows the dependence of the accumulator tank volume on the CHP heat capacity for 67 good practice projects in Europe, where CHP plants are combined with accumulator tanks.

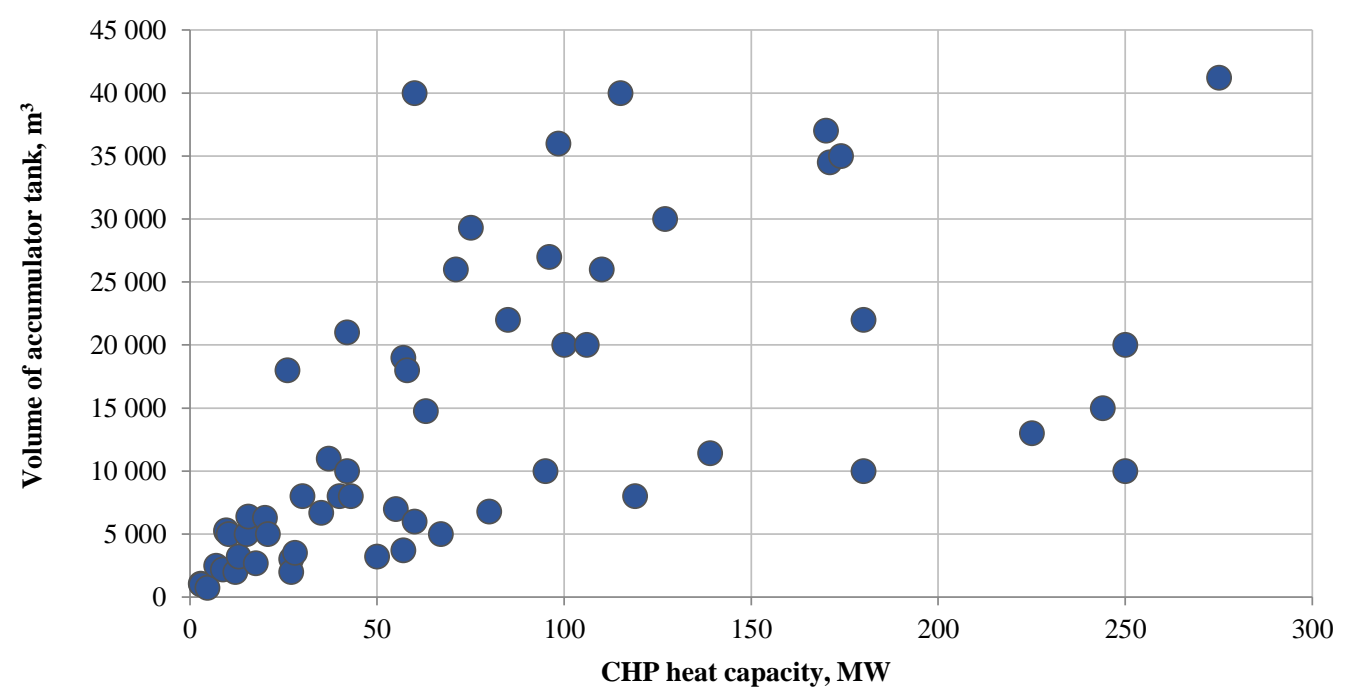

Fig. 1. Accumulator volume based on CHP heat capacity.

As mentioned earlier, there are a lot more accumulator tanks combined with CHP installed in Europe, but only the projects with complete technical information available were chosen for evaluation. The projects of 6 countries have been evaluated: Denmark (27 projects), Sweden (18 projects), Germany (9 projects), Finland (6 projects), Austria (4 projects), Netherlands (1 project), and Poland (2 projects). Accumulator tank size depends on the priority heat storage tasks, e.g., CHP system balancing; scheduling electricity and heat production to hours with the highest electricity cost but low heat load; replacing peak boilers.

In spite of the extensive use of CHP combined with accumulator tanks in European DH systems, these technologies have not been implemented in Estonia [26] or Latvia [27]. This can be due to the fact that new CHP plants are usually meant to provide base load energy throughout the year, therefore installing heat storage will not provide rapid payback.

The number of biomass CHPs has grown as a result of the national support policy for recently implemented biomass CHPs in Estonia. New CHPs are introduced to supply heat during the cold months when the heat load is quite high. Energy companies' enthusiasm for integrating heat storage into the DH system has grown in the past few years; still, to this day no company has introduced an accumulator tank to enhance biomass CHP operation process. A feasible explanation for such a setback could be that the biomass CHP support scheme is not limited to generating electricity only in CHP mode and utilising all heat and electricity generated at the same time on DH, it is allowed, that heat can be discharged into the atmosphere by the coolers. Additional auxiliary coolers can be installed to eliminate excess 
heat in the DH system during the lowest heat load period in the summer, as is done in Jarvenpaa biomass CHP (Finland) [28], Klaipeda waste incineration CHP (Lithuania) [29], and Parnu biomass CHP (Estonia) [30].

CHP production has not been a popular heat/electricity generation method in Estonia, alongside power generation from renewable fuel. But at the same time, the policy and goals for electricity generation implemented through European Union and local Estonian legislation have a major effect on the development process of biomass CHP plants. As stated in Estonia's National Development Plan for the Electricity sector until 2018, the target level for the share of renewable electricity in gross electricity consumption for 2010 was $5.1 \%$ and $15 \%$ for 2015 [31]. The target level for the share of CHP electricity in gross electricity consumption is $20 \%$ for 2020 . The real statistical data for the previously mentioned indicators in 2007 showed $1.8 \%$ and $10.2 \%$ respectively. Overall, the support scheme (the compulsory feed-in tariff was 51.77 EUR/MWh, which was nearly identical to the electricity production costs) has not been very efficient before May 2007. The principle idea of the policy was to offer reasonable profit to the most cost-efficient plants, which lead to a stagnation period, with no new plants built before 2007 when a few essential changes had been made to the support schemes for electricity generation from renewable sources and by CHP. According to the latest feed-in-premium (FIP) scheme, electricity from renewable energy sources (including biomass CHP) is sold on the electricity spot market, and producers get a premium (53.7 EUR/MWh) on top of the electricity market price. Because of FIP, new biomass CHP plants have been launched in every big city with a considerable DH heat load in Estonia (Tallinn, Parnu, and Tartu). The effect of the FIP implementation on electricity generated from renewable fuels, including biomass CHP, is depicted in Fig. 2.

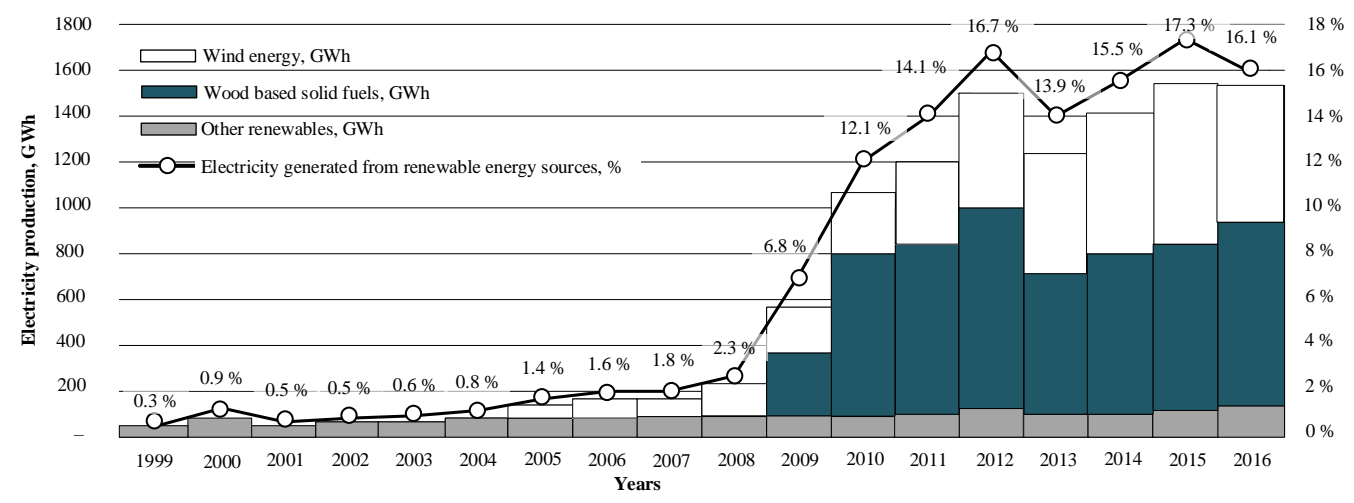

Fig. 2. Share of electricity generated from renewable fuel, and amount of electricity produced from renewable energy sources out of gross power consumption in Estonia.

It should be noted that, in accordance with the Electricity Market Act definition, biomass cogeneration process estimations vary from the efficient cogeneration process calculations. The key points of dissimilarity between the biomass CHP process and the efficient CHP process include:

- Efficient CHP is calculated by the month. The amount of electricity produced via an efficient CHP process is determined using the methods presented in Annex 2 to Directive 2004/8/EC of the European Parliament and of the Council;

- The biomass CHP process is calculated by the year. It is assumed that all electricity generated in a biomass-fuelled CHP plant was generated via a CHP process if the total yearly efficiency of the plant surpasses $40 \%$. If the total efficiency is less than 
$40 \%$, then the share of electricity generated through the cogeneration process out of the total electricity produced should be the same as the share of efficiently utilised heat (total heat production minus heat discharged into the atmosphere). It is obvious that the criteria for efficient cogeneration estimations are more precise than for biomass cogeneration process.

The FIP scheme permits power generation when heat is not used. Energy companies use air heat exchangers as auxiliary coolers to eliminate excess heat when the heat load in the DH system is insufficient.

Upon comparing this support scheme with those of other European countries, we can see that the latter use a wide range of tools to promote electricity production from biomass, including feed-in tariffs, feed-in-premium and green certificates. According to the Status Review of Renewable Energy Support Schemes in Europe, feed-in-premiums are implemented in Croatia, Czech Republic, Finland, Germany, France, the Netherlands, the United Kingdom, and Italy [32]. In all these countries, FIP is wholly or partially variable, it depends on the market price, and the cost of electricity produced equals the difference between the determined and market price. It can be stated that Estonia is the only country where FIP for electricity, generated from biomass, is completely independent of the market price. Besides, minimal annual energy efficiency of biomass CHP, as a mandatory criterion is low (yearly efficiency of the plant should be higher than $40 \%$ ). For example, in Finland, CHP is eligible for receiving premium tariffs only if the plant can achieve an efficiency of at least $50 \%$ or even $75 \%$. It can be explained by the fact that the Government of Estonia has set rather ambitious goals to increase the share of renewable energy in electricity production in a very short period of time, and, as can be seen in Fig. 2, implemented a support scheme that has significantly changed the structure of the electricity production energy source balance.

\section{METHODOLOGY}

Environmental and economic indicators were selected to assess the impact of the FIP scheme on the feasibility of integrating an accumulator tank into a biomass CHP-based DH system. Primary energy savings and avoided $\mathrm{CO}_{2}$ emissions due to the accumulator tank installation were chosen as environmental evaluation indicators. For economic evaluation, Net Present Value (NPV) and IRR of accumulator integration projects in variable conditions were chosen. Two scenarios with different support schemes have been analysed. For scenario evaluation, a model was constructed in EnergyPro software, using the biggest DH system in Estonia for reference. A block diagram of the DH system can be seen in Fig. 3.

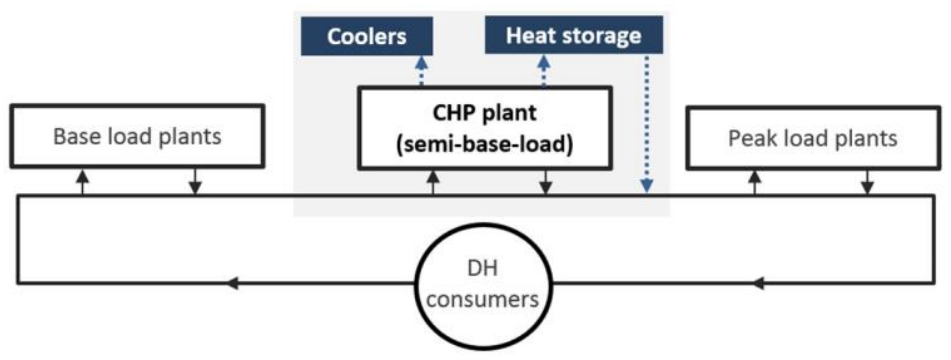

Fig. 3. Block diagram of the evaluated DH system. 
The model was built using the Tallinn district heating case study. Base load plants that provide heat for domestic hot water preparation and space heating throughout the year are biomass CHP, as well as a waste incineration plant. Peak load plants, gas-fired peak boilers operating during the high heat load periods (mostly during the winter months), are modelled as a single unit, as these boilers have nearly identical parameters. The last simulated energy unit is a biomass CHP installed for the semi-base load, supplying heat mostly in the spring, autumn, and winter. The semi-base load biomass CHP was launched in 2017, and has only worked in CHP mode (tracking heat load profiles) up until 2018, as there were no specialised facilities to discharge heat into the atmosphere. However, since 2018 it has been possible to generate electricity via heat discharge due to cooler installation. The viability of cooler and heat storage installation is dependent on the FIP scheme implementation features. Two key scenarios were simulated for the DH system:

- Scenario A: electricity generated by the biomass CHP is subsidised with the latest FIP scheme features. In this scenario, the heat that cannot be consumed or stored is discharged into the atmosphere by the coolers.

- Scenario B: only the power generated during the efficient CHP mode is subsidised. In this scenario, CHP works only when the heat load is adequate, and all the heat generated is consumed or stored.

In accordance with the heat load in Estonia, the accumulator tank can be utilised effectively during rapid air temperature changes, with the heat load changing throughout the day. In Estonia, these conditions are normally present during the months of May and October. Fig. 4 demonstrates an example of the operation strategy for CHP when all power generated by the CHP is subsidised (Scenario A).

In this case, the coolers are installed for heat discharge to increase power generation. Two weeks of May are provided as an example, demonstrating CHP working with and without an accumulator tank $\left(7000 \mathrm{~m}^{3}\right)$. Without the accumulator tank (Fig. 4(a)), when the heat load is lower than the CHP capacity, the CHP continues to work but the heat is partially discharged into the atmosphere; when the heat load is higher than CHP, peak boilers are turned on. If the accumulator tank is installed (Fig. 4(b)), the heat from CHP can be utilised in DH over a longer period of time. The amount of discharged heat diminishes, and the amount of heat transmitted to the DH network increases.

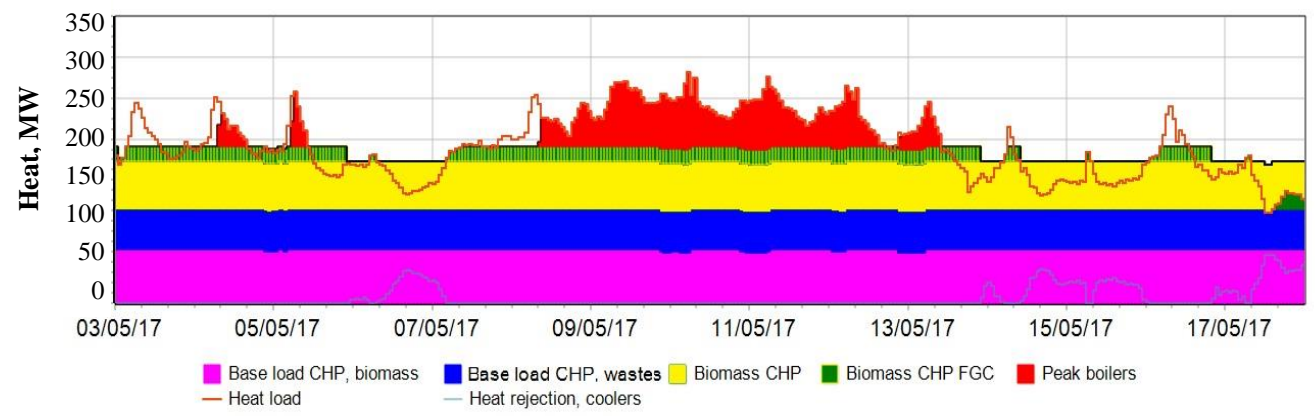

(a) 


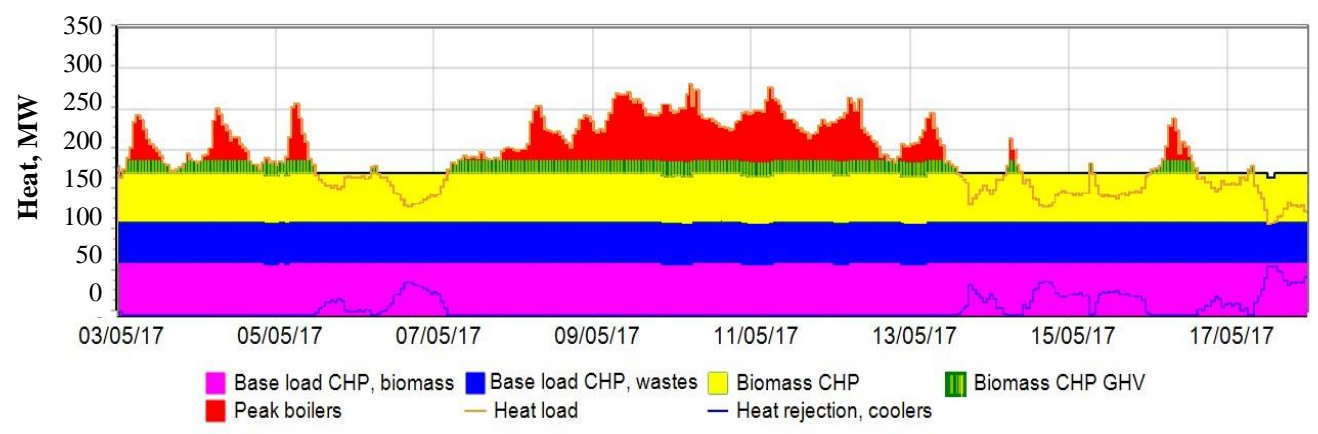

(b)

Fig. 4. Scenario A: example of CHP operation (a) without and (b) with an accumulator tank $\left(7000 \mathrm{~m}^{3}\right)$.

Fig. 5 depicts the situation, where only power generated during the CHP mode is subsidised, the coolers are not installed, and all the heat generated must be stored or consumed (Scenario B). When it is impossible to store the generated heat (Fig. 5(a)) and the heat load is lower than the CHP capacity, the DH operator turns off the CHP; and when the heat load is higher, peak boilers are utilised.

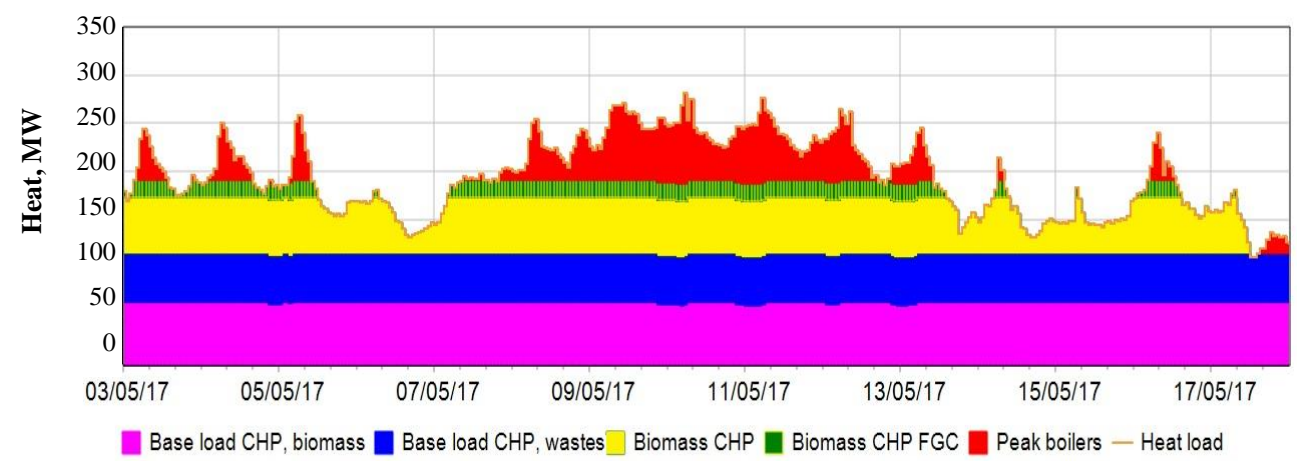

(a)

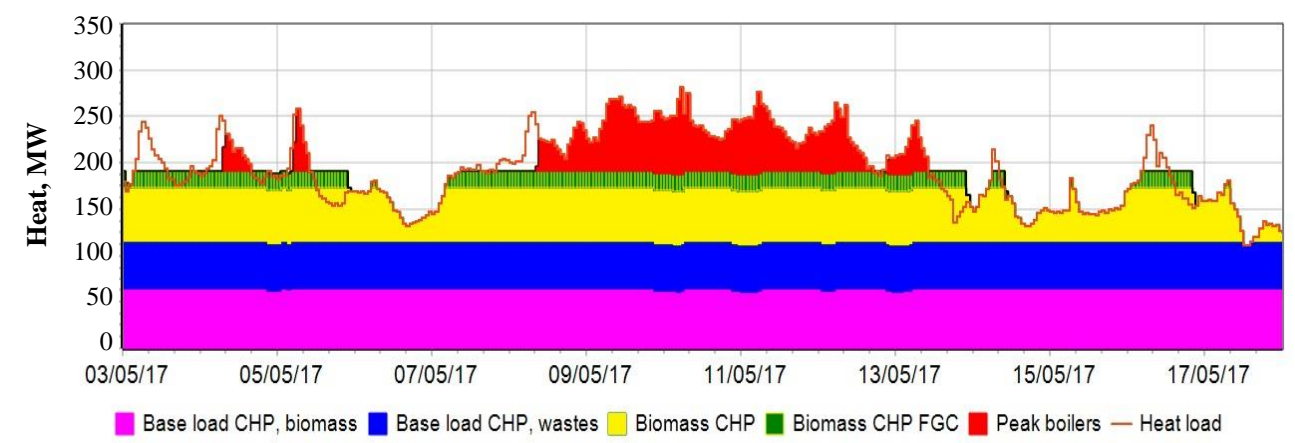

(b)

Fig. 5. Scenario B: Example of CHP operation (a) without and (b) with an accumulator tank $\left(7000 \mathrm{~m}^{3}\right)$. 
Fig. 5(b) demonstrates how installing an accumulator tank enhances the operational process. When the heat load is lower than the CHP installed capacity, the tank is charged by the surplus heat from CHP, and when the heat load is higher than the CHP installed capacity, the tank discharges and compensates the lack of heat while avoiding the use of peak boilers.

Fig. 6 portrays the charging-discharging of an accumulator tank. This operation strategy is suitable for both scenarios (Fig. 4(b) and Fig. 5(b)).

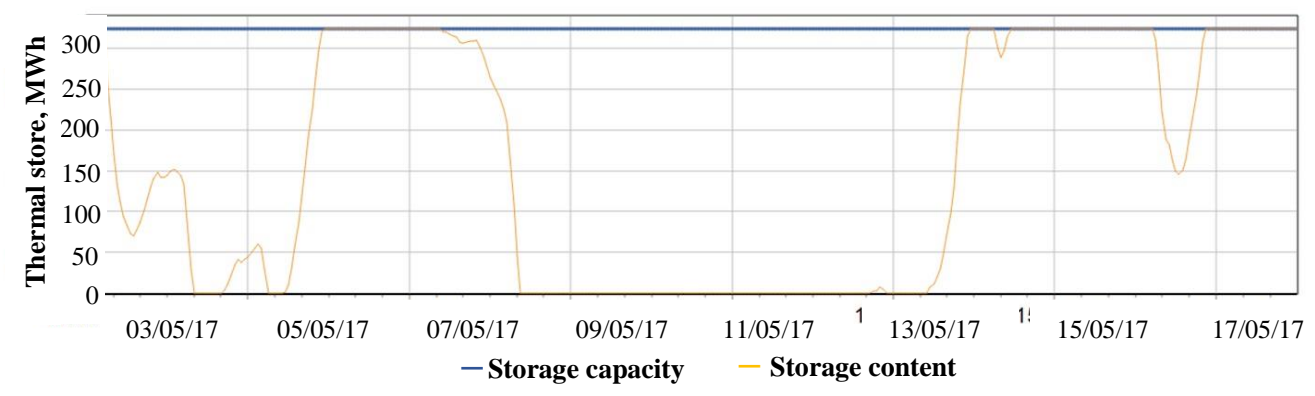

Fig. 6. Example of an accumulator tank $\left(7000 \mathrm{~m}^{3}\right)$ charging and discharging for scenarios A and B.

The calculations are based on the fact that the accumulator tank has a positive effect due to being able to charge from the heat during the transition period, but there are also other ways to use the accumulator tank. For instance, installing an accumulator tank aids $\mathrm{CHP}$ in preventing daily heat load changes [33], increases the stability of the DH system, and helps make the CHP operational strategy more flexible, based on electricity market price changes [26] that have not been considered in the simulations.

The main model input data and assumptions are:

- Biomass CHP capacity - heat capacity: $58 \mathrm{MW}$ (including flue gas condenser: $76 \mathrm{MW}$ ); power capacity: $21 \mathrm{MW}$; fuel consumed: wood chips; fuel input: $87 \mathrm{MW}$;

- Sum heat capacity of peak boilers: $900 \mathrm{MW}$; fuel consumed: natural gas; energy efficiency: $85 \%$;

- Capacities of base load plants are for biomass CHP heat capacity: $50 \mathrm{MW}$ (including flue gas condenser: $67 \mathrm{MW}$ ), power capacity: $25 \mathrm{MW}$. Waste incineration plant heat capacity: $50 \mathrm{MW}$;

- Heat load is based on 2017 historical data for the district heating area and is the same for all scenarios;

- Variable dimensions of the accumulator tank were considered from $1000 \mathrm{~m}^{3}$ up to $30000 \mathrm{~m}^{3}$. It was assumed that the temperature on top of the tank is $90{ }^{\circ} \mathrm{C}$, and $50{ }^{\circ} \mathrm{C}$ on the bottom. Other parameters used for accumulator heat loss calculation include insulation thickness $(300 \mathrm{~mm})$, and thermal conductivity $\left(0.037 \mathrm{~W} / \mathrm{m}^{\circ} \mathrm{C}\right)$;

- Economic inputs: electrical market prices are based on Nordpool historical data from 2017, FIP is $53.7 \mathrm{EUR} / \mathrm{MWh}_{\mathrm{el}}$; and wood fuel price: $12 \mathrm{EUR} / \mathrm{MWh}_{\text {fuel }}$; operational costs: $10 \mathrm{EUR} / \mathrm{MWh}_{\mathrm{th}}$; the selling price of heat distributed to the $\mathrm{DH}$ system is 34 EUR/MWh ${ }_{\text {th }}$; NPV based on the expected IRR: $7 \%$; calculated duration: 12 years. The costs of tank installation are based on the 'Technology Data for Energy Plants' catalogue provided by the Danish Energy Agency [34];

- $\mathrm{CO}_{2}$ emission factors and primary energy factors are based on Estonian regulations and shown in Table 1. 
It should be noted that the $\mathrm{CO}_{2}$ emission factor is very high in Estonia due to the high proportion of local fossil fuel (oil shale) in local electricity production [35]. Estonia has one of the highest $\mathrm{CO}_{2}$ emission rates per capita in the world [36].

TABle 1. Primary Energy FaCtors And $\mathrm{CO}_{2}$ EMISSION FACTORS IN Estonia [37], [38]

\begin{tabular}{lll}
\hline & Primary energy factor & $\begin{array}{l}\mathrm{CO}_{2} \text { emission factor, } \\
\mathrm{tCO}_{2} / \mathrm{MWh}\end{array}$ \\
\hline Natural gas & 1 & 0.198 \\
Biomass fuel & 0.75 & 0 \\
Electricity & 2 & 0.98 \\
\hline
\end{tabular}

\section{RESUlts}

Once the scenarios were simulated for a variety of heat storage sizes, economic parameters NPV and IRR were estimated for each scenario (Fig. 7). Usually NPV evaluation presents a result that forms the foundation for an investment decision and the IRR method generates the percentage return that the project is expected to create. For scenario A, the perfect accumulator tank size should be around $2000 \mathrm{~m}^{3}$. It is rather small and, when compared to the best practice examples shown in Fig. 1, it is evident that the size range for such type and capacity of CHP accumulator tanks starts at $3200 \mathrm{~m}^{3}$. For scenario B, where only the power generated during the biomass CHP mode is subsidised, based on NPV parameter, the optimal size of the accumulator tank is around $7000 \mathrm{~m}^{3}$. IRR is much higher for scenario $\mathrm{B}$, as opposed to scenario A. For scenario A, the installation of the accumulator tank leads to an increase in revenue due to the sale of heat that had not been discharged into the atmosphere, but stored and subsequently distributed over DH. In scenario A, the annual net cash flow is much higher, because electricity market prices and premium are added to it, along with heat sale revenue.

Fig. 8(a) demonstrates an increase in primary energy savings as a result of installing an accumulator tank. Fig. 8(b) depicts the amount of $\mathrm{CO}_{2}$ emissions that can be eliminated as a result of installing an accumulator tank for scenarios $\mathrm{A}$ and $\mathrm{B}$.

In scenario B with the accumulator tank installed, it is possible to generate more power and heat, which means that $\mathrm{CO}_{2}$ emissions will be reduced as a result of eliminating gas boiler heat generation and power plant electricity generation. However, in scenario A with power generated by $\mathrm{CHP}$, regardless of whether the heat is used or not, only $\mathrm{CO}_{2}$ emissions from gas boilers are eliminated. This means that using accumulator tanks in scenario A leads to a significantly smaller $\mathrm{CO}_{2}$ emission reduction. Concerning the primary energy savings for scenario $\mathrm{A}$, once the heat is rejected, integrating an accumulator tank makes it possible to increase CHP heat consumption and decrease natural gas use. In scenario A, generated power and consumed biomass fuel do not depend on heat storage size, and remain the same in all cases. For scenario B, integrating an accumulator tank leads to alterations in power generation, biomass fuel and natural gas use. Calculation results demonstrate that the primary energy savings for the DH system in this case study are nearly identical in both scenarios. 


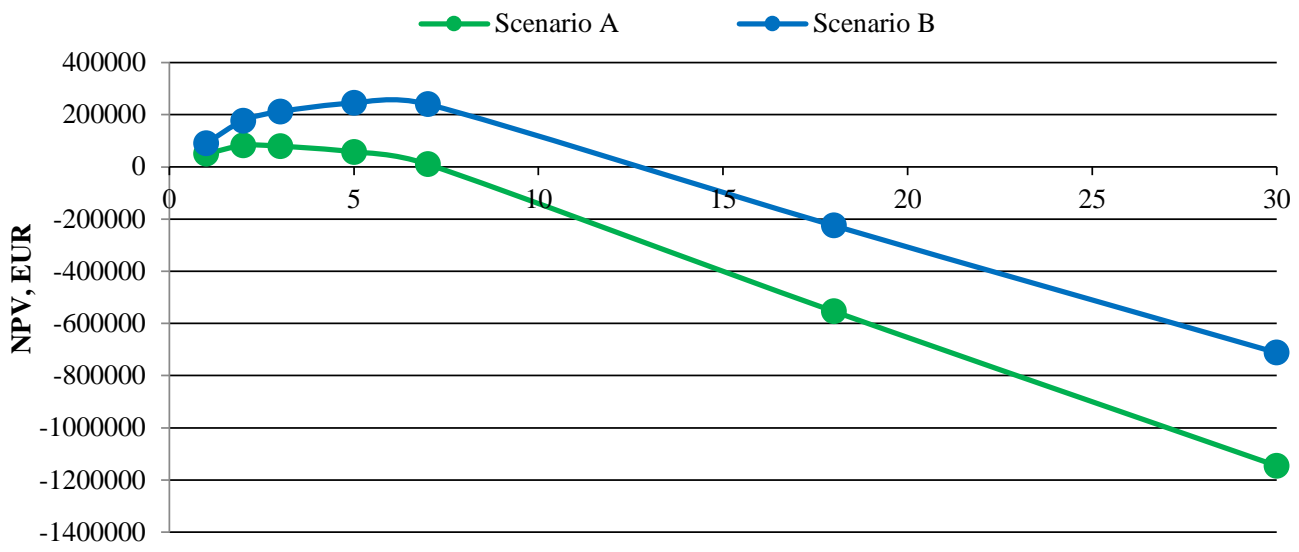

Tank volume, $1000 \mathrm{~m}^{3}$

(a)

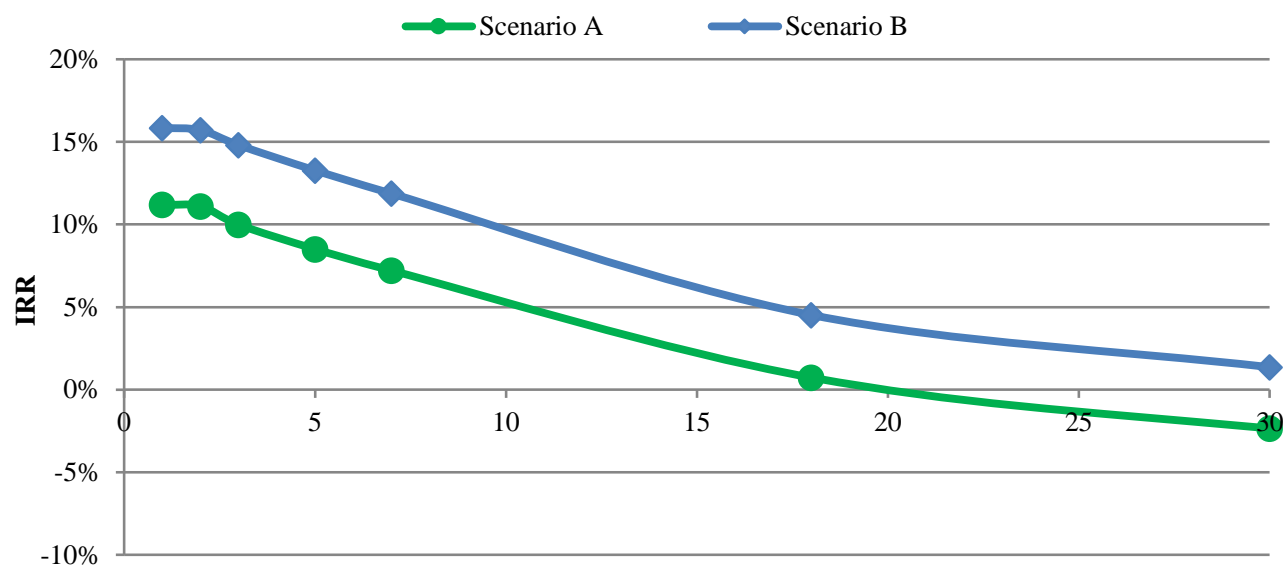

Tank volume, $1000 \mathrm{~m}^{3}$

(b)

Fig. 7. Economic indicators (a) NPV and (b) IRR, based on heat storage size.

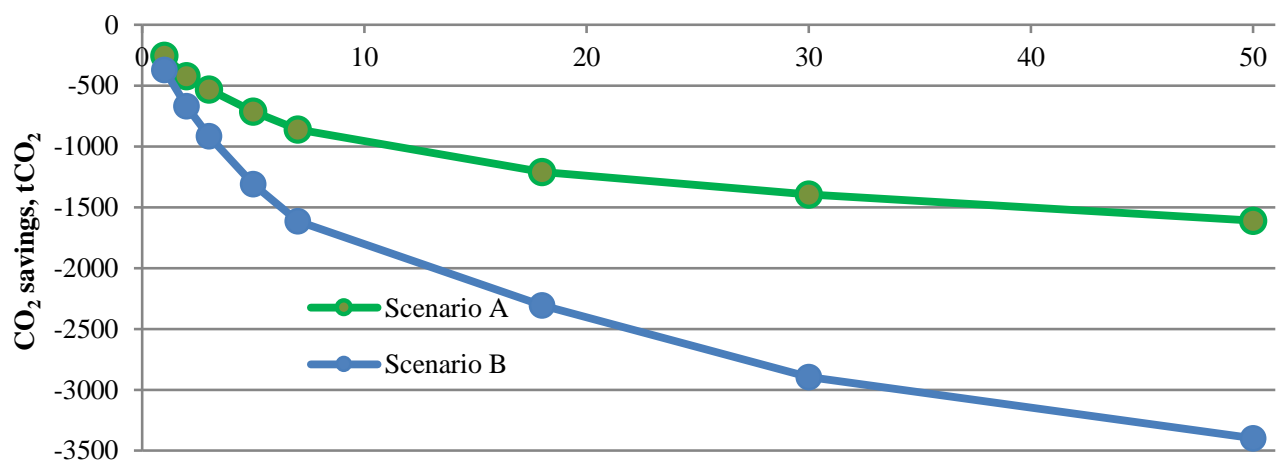

Volume of accumulator tank, $1000 \mathrm{~m}^{3}$

(a) 


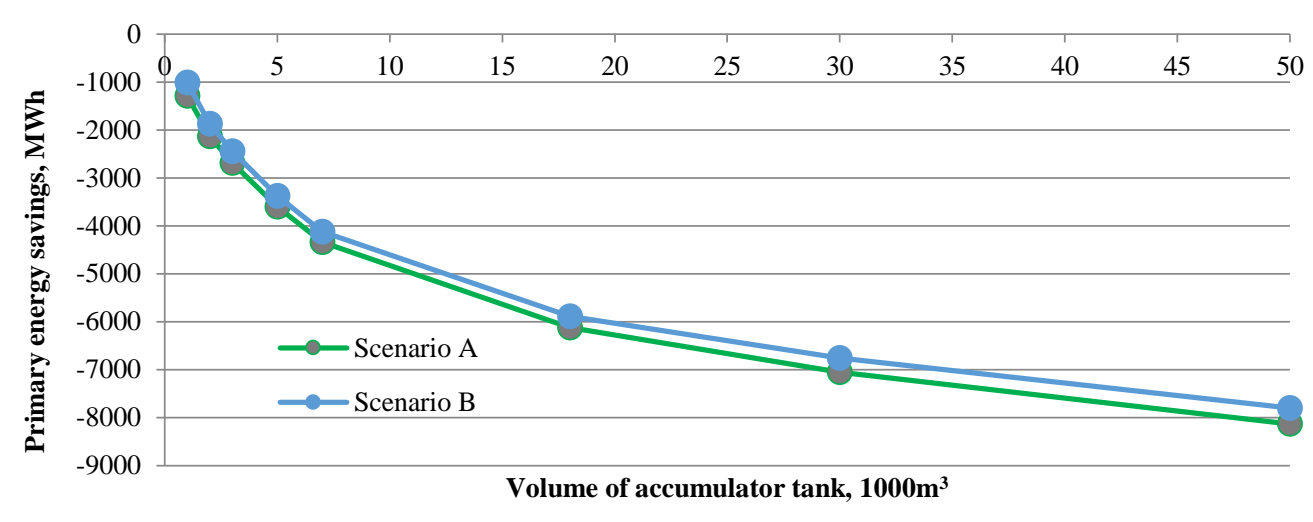

(b)

Fig. 8. Environmental indicators: (a) primary energy savings based on heat storage size; (b) $\mathrm{CO}_{2}$ emission savings, based on heat storage size.

\section{CONClusion ANd Discussions}

Accumulator tanks are a popular option for enhancing the biomass CHP operation in Europe. Because of the FIP scheme, many new biomass CHPs have been launched in Estonia, albeit without integrating accumulator tanks into a CHP-based DH system. The current FIP support scheme allows the DH operator to generate power using CHP and reject the heat when the heat load is insufficient. The goal of the study was to assess how Estonia's FIP support scheme affects the viability of integrating the heat storage unit into the DH system. A large DH system (Tallinn, Estonia) was used in this case study, and a model of that system was built to simulate two scenarios: the first scenario with the FIP support scheme, where all power generated by biomass CHP is subsidised; and the second scenario, where only the power generated during the CHP mode is subsidised. The study determined that in the conditions of the FIP support scheme, heat storage integration is less reliable. Besides, the reduction of $\mathrm{CO}_{2}$ emissions is less significant, compared to the scenario, where CHP cannot discharge heat into the atmosphere. When only the power generated during the CHP mode is subsidised, integrating an accumulator tank has a favourable impact on the economic parameters: NPV is positive and IRR is high. $\mathrm{CO}_{2}$ emission reduction is much more significant for this type of support.

Additionally, with the existing support scheme, the optimal size of an accumulator tank, according to NPV for 12 years, is about $2000 \mathrm{~m}^{3}$, which is very low, compared to the similar projects realised in other European countries. The combination of heat rejection and heat storage, combined with CHP within the DH system has a negative impact on accumulator tank feasibility. By way of examining the actual situation with the national renewable energy support scheme and energy sector development over the last decade, it was concluded that the FIP support scheme is too primitive and can lead to over-subsidising in the energy sector. When comparing FIP support schemes in Estonia with similar cases in other European countries, it should be noted that these countries implement more complex and individualised schemes based on both energy source characteristics and electricity market prices. On the one hand, this enterprise-friendly scheme has led to a very rapid increase in renewable energy production in Estonia, but on the other hand, the overall energy production efficiency from biomass may decrease. The current FIP scheme makes it possible to install additional coolers at the biomass CHP to discharge the heat into the atmosphere during the low heat load period. 
Accumulator tanks can be a good solution for the longer efficient CHP operation period throughout the year. However, when CHP remains in operation even if the heat load is insufficient, and continues to generate electricity throughout the year, the feasibility of installing an accumulator tank decreases significantly.

\section{ACKNOWLEDGEMENT}

This study was supported by Estonia's Ministry of Education and Research (project-based funding B55).

\section{REFERENCES}

[1] Galindo Fernandez M., Roger-Lacan C., Gahrs U., Aumaitre V. Efficient district heating and cooling systems in the EU Case studies analysis, replicable key success factors and potential policy implications. Publication Office of the European Union, 2016. https://doi.org/10.2760/371045

[2] Mashatin V., Link S., Siirde A. The Impact of Alternative Heat Supply Options on $\mathrm{CO}_{2}$ Emission and District Heating System. Chemical Engineering Transactions 2014:39:1105-1110. https://doi.org/10.3303/CET1439185

[3] Connolly D., Mathiesen B. V., Ostergaard P. A., Lund H., Werner S., Moller B., Persson U., Boermans T., Trier D., Nielsen S. Heat Roadmap Europe: Combining district heating with heat savings to decarbonise the EU energy system. Energy Policy 2014:65:475-489. https://doi.org/10.1016/j.enpol.2013.10.035

[4] Latosov E., Volkova A., Siirde A., Thalfeldt M., Kurnitski J. The Impact of Parallel Energy Consumption on the District Heating Networks. Environmental and Climate Technologies 2019:23(1):1-13. https://doi.org/10.2478/rtuect-2019-0001

[5] Vigants E., Prodanuks T., Vigants G., Veidenbergs I. Modelling of Technological Solutions to $4^{\text {th }}$ Generation DH Systems. Environmental and Climate Technologies 2017:20:5-23. https://doi.org/10.1515/rtuect-2017-0007

[6] Latosov E., Volkova A., Siirde A., Kurnitski J., Thalfeldt M. Primary energy factor for district heating networks in European Union member states. Energy Procedia 2017:116:69-77. https://doi.org/10.1016/j.egypro.2017.05.056

[7] Pakere I., Romagnoli F., Blumberga D. Introduction of small-scale $4^{\text {th }}$ generation district heating system. Methodology approach. Energy Procedia 2018:149:549-554. https://doi.org/10.1016/j.egypro.2018.08.219

[8] Lund H., Werner S., Wiltshire S., Svendsen S., Thorsen J. E., Hvelplund F., Mathiesen B. V. $4^{\text {th }}$ Generation District Heating (4GDH). Integrating smart thermal grids into future sustainable energy systems. Energy 2014:68:1-11. https://doi.org/10.1016/j.energy.2014.02.089

[9] Ziemele J., Gravelsins A., Blumberga A., Vigants G., Blumberga D. System dynamics model analysis of pathway to 4th generation district heating in Latvia. Energy 2016:110:85-94. https://doi.org/10.1016/j.energy.2015.11.073

[10] Lund H., Ostergaard P. A., Connolly D., Mathiesen B. V. Smart energy and smart energy systems. Energy 2017:137:556-565. https://doi.org/10.1016/j.energy.2017.05.123

[11] Nuytten T., Claessens B., Paredis K., Van Bael J., Six D. Flexibility of a combined heat and power system with thermal energy storage for district heating. Applied Energy 2013:104:583-591. https://doi.org/10.1016/j.apenergy.2012.11.029

[12] Meffre A., Xavier P., Olives R., Bessada C., Veron E., Echegut P. High-Temperature Sensible Heat-Based Thermal Energy Storage Materials Made of Vitrified MSWI Fly Ashes. Waste and Biomass Valorization 2015:6(6):1003-1014. https://doi.org/10.1007/s12649-015-9409-9

[13] Karner K., Mckenna R., Klobasa M., Kienberger T. Industrial excess heat recovery in industry-city networks: a technical, environmental and economic assessment of heat flexibility. Journal of Cleaner Production 2018:193:771-783. https://doi.org/10.1016/j.jclepro.2018.05.045

[14] Bauer D., Marx R., Nußbicker-Lux J., Ochs F., Heidemann W., Muller-Steinhagen H. German central solar heating plants with seasonal heat storage. Solar Energy 2010:84(4):612-623. https://doi.org/10.1016/j.solener.2009.05.013

[15] Ciampi G., Rosato A., Sibilio S. Thermo-economic sensitivity analysis by dynamic simulations of a small Italian solar district heating system with a seasonal borehole thermal energy storage. Energy 2018:143:757-771. https://doi.org/10.1016/j.energy.2017.11.029

[16] Soloha R., Pakere I., Blumberga D. Solar energy use in district heating systems. A case study in Latvia. Energy 2017:137:586-594. https://doi.org/10.1016/j.energy.2017.04.151

[17] Verda V., Colella F. Primary energy savings through thermal storage in district heating networks. Energy 2011:36(7):4278-4286. https://doi.org/10.1016/j.energy.2011.04.015

[18] Noussan M., Cerino-Abdin G., Poggio A., Roberto R. Biomass-fired CHP and heat storage system simulations in existing district heating systems. Applied Thermal Engineering 2014:71(2):729-735. https://doi.org/10.1016/j.applthermaleng.2013.11.021 
[19] Wang H., Yin W., Abdollahi E., Lahdelma R., Jiao W. Modelling and optimization of CHP based district heating system with renewable energy production and energy storage. Applied Energy 2015:159:401-421. https://doi.org/10.1016/j.apenergy.2015.09.020

[20] Streckiene G., Miseviciute V. Research of Operation Modes of Heat Storage Tank in CHP Plant Using Numerical Simulation. Environmental and Climate Technologies 2012:6:91-99. https://doi.org/10.2478/v10145-011-0013-3

[21] Cabeza L. F., Martorell I., Miro L., Fernandez A. I., Barreneche C. Introduction to thermal energy storage (TES) systems. Advances in Thermal Energy Storage Systems 2015:1-28. https://doi.org/10.1533/9781782420965.1

[22] Gadd H., Werner S. Thermal energy storage systems for district heating and cooling. Advances in Thermal Energy Storage Systems 2015:467-478. https://doi.org/10.1533/9781782420965.4.467

[23] Nordvarme. Korttidslagring av varmt vand i tanke over jorden (Short-term storage of hot water in tanks above ground), 1993. (in Swedish)

[24] Smith A. D., Mago P. J., Fumo N. Benefits of thermal energy storage option combined with CHP system for different commercial building types. Sustainable Energy Technologies and Assessments 2013:1:3-12. https://doi.org/10.1016/j.seta.2012.11.001

[25] Andrews D., Pardo-Garcia N., Krook-Riekkola A., Tzimas E., Serpa J., Carlsson J., Papaioannou I. Background Report on EU-27 District Heating and Cooling Potentials, Barriers, Best Practice and Measures of Promotion. JRC Scientific and Policy Report 2012. https://setis.ec.europa.eu/system/files/1.DHCpotentials.pdf

[26] Volkova A., Hlebnikov A., Siirde A. Simulation of the accumulator tank coupled with the power unit of power plant under the conditions of open electricity market. Chemical Engineering Transactions 2012:29:757-762. https://doi.org/10.3303/CET1229127

[27] Pakere I., Purina D., Blumberga D., Bolonina A. Evaluation of Thermal Energy Storage Capacity by Heat Load Analyses. Energy Procedia 2016:95:377-384. https://doi.org/10.1016/j.egypro.2016.09.040

[28] Hast A., Rinne S., Syri S., Kiviluoma J. The role of heat storages in facilitating the adaptation of district heating systems to large amount of variable renewable electricity. Energy 2017:137:775-788. https://doi.org/10.1016/j.energy.2017.05.113

[29] Penttila K. E. Waste-to-Energy Plant as Part of Combined Heat and Power Strategy - Using the Example of the Klaipeda Case. Importance of circular economy is growing. TK Verlag Karl Thome-Kozmiensky, 2012.

[30] CODE2. Case study factsheet Parnu, Estonia, Parnu CHP plant, 2014 [Online]. Available: http://www.code2project.eu/wp-content/uploads/CODE2-BPC-ES-Parnu-CHP-v1.pdf

[31] Government of the Republic of Estonia. National Development Plan of the Energy Sector until 2030, 2017 [Online]. Available: https://www.mkm.ee/sites/default/files/ndpes_2030_eng.pdf

[32] Council of European Energy Regulators, Status Review of Renewable Support Schemes in Europe, 2017 [Online]. Available: https://www.ceer.eu/documents/104400/-/-/41df1bfe-d740-1835-9630-4e4cccaf8173

[33] Ziemele J., Pakere I., Chernovska L., Blumberga D. Lowering Temperature Regime in District Heating Network for Existing Building Stock. Chemical Engineering Transactions 2016:52:709-714. doi:10.3303/CET1652119

[34] Danish Energy Agency. Individual Heating Plants and Energy Transport Technology Data for Energy Plants, 2012.

[35] Loo L., Maaten B., Konist A., Siirde A., Neshumayev D., Pihu T. Carbon dioxide emission factors for oxy-fuel CFBC and aqueous carbonation of the Ca-rich oil shale ash. Energy Procedia 2017:128:144-149. https://doi.org/10.1016/j.egypro.2017.09.034

[36] Konist A., Maaten B., Loo L., Neshumayev D., Pihu T. Mineral Sequestration of $\mathrm{CO}_{2}$ by Carboation of Ca-Rich Oil Shale Ash in Natural Conditions. Oil Shale 2016:33(3):248-259. https://doi.org/10.3176/oil.2016.3.04

[37] Latosov E., Kurnitski J., Thalfeldt M., Volkova A. Primary Energy Factors for Different District Heating Networks: An Estonian Example. Energy Procedia 2016:96:674-684. https://doi.org/10.1016/j.egypro.2016.09.126

[38] Government of Republic of Estonia. Minimum requirements for energy performance RT I, 2015.

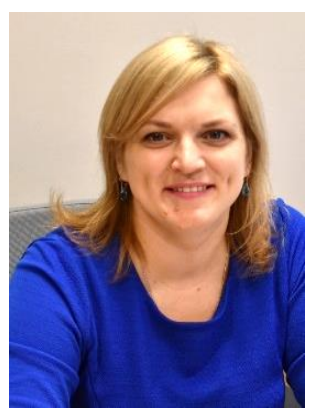

Anna Volkova, Dr. sc. ing. senior researcher in Department of Energy Technology, Tallinn University of Technology. She defended PhD thesis in 2008, in Riga Technical University (Latvia). Anna Volkova has been as a postdoc researcher and later senior researcher since 2009 in Department of Energy Technology, Tallinn University of Technology (Estonia). Anna Volkova is author and co-author of more than 30 scientific publications. The main research topics are district heating, thermal energy storage, CHP and energy efficiency.

ORCID iD: https://orcid.org/0000-0002-3802-3510 


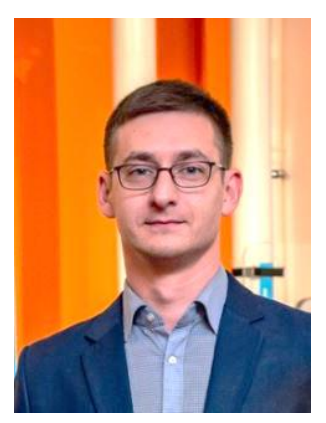

Eduard Latosov, PhD, assistant professor in Department of Energy Technology, Tallinn University of Technology. He defended PhD thesis in 2011, in Tallinn University of Technology. Starting from 2015 he works in the Department of Energy Technology, Tallinn University of Technology (Estonia). Eduard Latosov is author and co-author of more than 20 scientific publications. The main research topics are district heating, CHP, primary energy and energy efficiency. Address: Ehitajate tee 5, 19086, Tallinn, Estonia.

ORCID iD: https://orcid.org/0000-0002-2085-4471

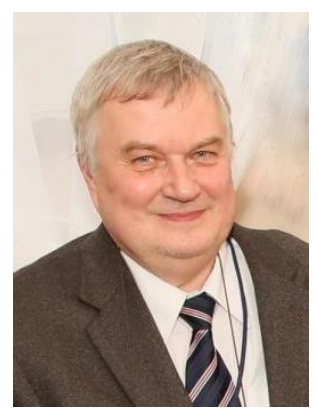

Andres Siirde, PhD, professor, Director of Department of Energy Technology of the Tallinn University of Technology. He received Industrial Thermal Power Engineer Diploma (1980) and doctoral degree (1984). The main research areas are oil shale, cogeneration, SEG emissions, and energy efficiency. A. Siirde has been a part of academic staff of TUT since 1984. A. Siirde is author of more than 70 publications.

ORCID iD: https://orcid.org/0000-0002-2352-6983 